\title{
Distribution of trace elements in sphalerite and arsenopyrite on the nanometre-scale - discrete phases versus solid solution
}

\author{
Simon GOLDMANN ${ }^{1, *}$, Malte JUNGE ${ }^{1,2, a}$, Richard WIRTH $^{3}$ and ANJa SCHREIBER ${ }^{3}$ \\ ${ }^{1}$ Federal Institute for Geosciences and Natural Resources (BGR), Stilleweg 2, 30655 Hannover, Germany \\ *Corresponding author, e-mail: simon.goldmann@bgr.de \\ ${ }^{2}$ Institute of Earth and Environmental Sciences, University of Freiburg, Albertstr. 23b, 79104 Freiburg, Germany \\ ${ }^{3}$ Helmholtz Centre Potsdam, GFZ German Research Centre for Geosciences, Department 4.4, Telegrafenberg, \\ 14473 Potsdam, Germany \\ ${ }^{a}$ formerly BGR, now University of Freiburg.
}

\begin{abstract}
Sphalerite and arsenopyrite can host trace elements (e.g., $\mathrm{Ge}, \mathrm{Cd}$ and $\mathrm{Au}$ ) that are important for high technology applications. These trace elements are incorporated into the structure of the host mineral (e.g., by substitution) if inclusions are apparently absent. Focused ion beam technique and transmission electron microscopy combined with electron microprobe analysis allow for the correlation from micrometre to the nanometre scale in order to investigate the locations of trace elements in situ within the host minerals. Therefore, Ge-rich sphalerite from the Tres Marias $\mathrm{Zn}-\mathrm{Pb}-\mathrm{Ge}$ deposit in Mexico and auriferous arsenopyrite from the Ashanti Au mine in Ghana are investigated. Sphalerite from Tres Marias contains Ge concentrations of up to $1430 \mu \mathrm{g} / \mathrm{g}$ and is characterised by elevated Fe contents. Germanium is homogeneously distributed within the sphalerite lattice without the presence of distinct Ge-bearing phases in the form of inclusions or exsolutions. In arsenopyrite from the Ashanti mine, Au occurs as oriented sub-microscopic discrete phases showing at least two distinct orientations, which cause the observed trace-element concentrations visible at larger scale. The formation of nanometre-sized gold particles in arsenopyrite is interpreted as enrichment of Au at the interface of crystallising arsenopyrite with the hydrothermal fluid and subsequent crystallisation of nanometre-sized gold grains at the surface of arsenopyrite after the critical concentration for nucleation was overstepped.
\end{abstract}

Key-words: FIB-TEM; EPMA; trace elements; inclusions; solid solution; sphalerite; germanium; arsenopyrite; gold.

\section{Introduction}

Trace elements in ore minerals are of economic importance as they can be valuable by-products or even represent the main economic value of a deposit. The textures of ore minerals and the siting of trace elements within ore minerals are important for ore processing and can reveal the genetic history of an ore deposit. For "classic" ore minerals like sphalerite ( $\mathrm{ZnS})$ and arsenopyrite (FeAsS) it is commonly assumed that trace elements are incorporated into the crystal lattice of the host mineral (e.g., by substitution) if inclusions are apparently absent.

So far, trace element concentrations of sphalerite and arsenopyrite were studied using analytical methods (e.g., Cabri et al., 1984, 1989; Cook \& Chryssoulis, 1990; Oberthür et al., 1994, 1997; Cook et al., 2009, 2013, 2016; Saini-Eidukat et al., 2009, 2016), such as Electron Probe Microanalysis (EPMA), Particle-Induced X-ray Emission (PIXE), Secondary Ion Mass Spectrometry (SIMS), LaserAblation Inductively Coupled Plasma Mass Spectrometry (LA-ICP-MS), and X-ray Absorption Near Edge Structure (XANES). These studies showed that both Ge concentrations in sphalerite and $\mathrm{Au}$ contents in arsenopyrite can be in the
$100 \mu \mathrm{g} / \mathrm{g}$ range up to a few weight percent. However, the drawback of these analytical methods is the spatial resolution as beam sizes are typically in the range of 1 to $>50 \mu \mathrm{m}$. The technical improvement of Transmission Electron Microscopy (TEM) and the development of a combination of Focused Ion Beam (FIB) with TEM allows to link the observations on the $\mu \mathrm{m}$ scale using conventional methods with the nm scale of TEM (Wirth, 2004, 2009). Therefore, in order to investigate the siting of trace elements in situ in the host minerals on a sub- $\mu \mathrm{m}$ scale, a combination of FIB-TEM and EPMA is applied. Preparation of FIB foils for TEM studies with applications in geosciences exists for about 15 years (Wirth, 2004, 2009), but this technique has only occasionally been applied to problems related to ore genesis (e.g., Cook et al., 2009; Ciobanu et al., 2011, 2017; Wirth et al., 2013). For example, Wirth et al. (2013) and Junge et al. (2015) used a combination of FIB and TEM to document the presence of nm-sized discrete platinum-group mineral inclusions in sulphides from the Bushveld Complex, South Africa.

This study uses a FIB-TEM approach combined with EPMA to link the observation on the $\mu \mathrm{m}$-scale with the $\mathrm{nm}$-sized distribution of $\mathrm{Ge}$ in sphalerite and $\mathrm{Au}$ in arsenopyrite. 


\section{Previous work}

\subsection{Sphalerite}

Sphalerite is the most important ore mineral for Zn, but may host a broad range of minor and trace elements that could represent valuable by-products (Fleischer, 1955; Johan, 1988; Cook et al., 2009, 2015; Ciobanu et al., 2011; Ye et al., 2011; Belissont et al., 2014). Similarities in size and valence of these minor and trace elements compared to the tetrahedrally coordinated $\mathrm{Zn}$, facilitates substitution for $\mathrm{Zn}$ in the sphalerite structure (e.g., Cook et al., 2009). Germanium is of special interest as it is an important element for high-technology applications, such as fibre optic systems, infrared optics, polymerisation catalysts, and lightemitting diodes (Melcher \& Buchholz, 2014; Cook et al., 2015). Economically important sources are either Ge-rich coal seams or sphalerite from $\mathrm{Pb}-\mathrm{Zn}$ sulphide deposits formed at relatively low temperatures (Bernstein, 1985; Höll et al., 2007; Seredin, 2012; Melcher \& Buchholz, 2014; Cook et al., 2016). Sphalerite may contain remarkable $\mathrm{Ge}$ concentrations of up to $3000 \mu \mathrm{g} / \mathrm{g}$ (Bernstein, 1985; Höll et al., 2007; Cook et al., 2009; Melcher \& Buchholz, 2014).

It is assumed that $\mathrm{Zn}^{2+}$ in sphalerite is either directly substituted by $\mathrm{Ge}^{2+}$ or by $\mathrm{Ge}^{4+}$, which generates vacancies in the sphalerite structure to compensate charge (Cook et al., 2009, 2015). However, the presence of $\mathrm{Ge}^{4+}$ in sphalerite is more reasonable as this is the dominant species occurring in the environment and in natural compounds (Belissont et al., 2014). Additionally, $\mathrm{Ge}^{4+}$ was determined by XANES data in sphalerite from Tres Marias (Cook et al., 2015). Other authors suggest coupled substitution with $\mathrm{Cu}$ and $\mathrm{Ag}$ based on correlation of these elements with $\mathrm{Ge}$ (Bernstein, 1985; Johan, 1988; Cook et al., 2009; Belissont et al., 2014). The presence of metals like $\mathrm{Cu}$ and Ag possibly enhances the ability to incorporate other trace elements (Belissont et al., 2014).

\subsection{Arsenopyrite}

Gold generally occurs as native free-milling gold or as refractory (also termed "invisible") $\mathrm{Au}$ incorporated in sulphides, especially arsenopyrite. Both types may occur side by side within a single deposit (Oberthür et al., 1994, 1997). Refractory $\mathrm{Au}$ is either present in the form of nm-sized particles or occurs lattice-bound in the crystal structure (solid solution) of the host mineral (e.g., Cabri et al., 1989; Sung et al., 2009), but both styles are mutually exclusive (Cabri et al., 2000). Rather high Au contents of up to $1.52 \mathrm{wt} \%$ are reported for natural arsenopyrite (Johan et al., 1989), but also synthetic arsenopyrite containing up to $3 \mathrm{wt} \% \mathrm{Au}$ has been prepared (Fleet \& Mumin, 1997). Refractory $\mathrm{Au}$ is heterogeneously distributed and related to growth zones, which is interpreted as Au being cogenetic with the hosting arsenopyrite (Cathelineau et al., 1989; Fleet \& Mumin, 1997; Cabri et al., 2000; Sung et al., 2009). In general, Au-bearing arsenopyrite is deficient in As compared to its stoichiometric composition (Genkin et al., 1998; Yang et al., 1998; Vaughan \& Kyin, 2004; Sung et al., 2009).
However, the opposite trend that high $\mathrm{Au}$ contents in arsenopyrite correlate with excess in As and deficiency in Fe are also reported (Cathelineau et al., 1989; Fleet \& Mumin, 1997; Cepedal et al., 2008). Incorporation of lattice-bound $\mathrm{Au}$ into arsenopyrite may result from substitution of $\mathrm{Fe}$ by $\mathrm{Au}$ as both elements show negative correlation (Yang et al., 1998; McClenaghan et al., 2004; Sung et al., 2009), but other authors (Genkin et al., 1998) did not observe this correlation.

\section{Methods and origin of samples}

Following conventional methods of study using ore microscopy, Scanning Electron Microscopy (SEM) and EPMA, four electron-transparent foils of sphalerite (\#4932, \#4933, \#4934, \#4937) from the Tres Marias deposit in Mexico (Figs. 1a-1c) and five foils of arsenopyrite (\#4959, \#4961, \#4964, \#4966, \#4969) from the Ashanti mine in Ghana (Figs. 1d and 1e) were prepared with FIB at the German Research Centre for Geosciences (GFZ) in Potsdam.

The sphalerite sample (AS7885a, TM06-07) originates from the Tres Marias $\mathrm{Zn}-\mathrm{Pb}-\mathrm{Ge}$ deposit in Mexico, which contains sphalerite and willemite with extraordinary high $\mathrm{Ge}$ contents (Saini-Eidukat et al., 2009). The ore body occurs in a carbonate dissolution collapse breccia hosted by a midCretaceous carbonate sequence (Saini-Eidukat et al., 2009; Ostendorf et al., 2017). Mineralisation was dated at $28.8 \mathrm{Ma}$ using $\mathrm{Rb}-\mathrm{Sr}$ geochronology on sphalerite (Ostendorf et al., 2017). Sphalerite occurs as spheroidal aggregates with a distinctive bladed or lamellar texture in the cores. Highest Ge concentrations are related to high-Fe sphalerite (Saini-Eidukat et al., 2009; Cook et al., 2009, 2015). Saini-Eidukat et al. (2009) analysed Fe-rich sphalerite by EPMA resulting in an average $(n=47)$ composition of $9.9 \mathrm{wt} \% \mathrm{Fe}$ and $800 \mu \mathrm{g} / \mathrm{g} \mathrm{Ge}$. Analysis by Cook et al. (2009) using LA-ICP-MS gave similar results with an average $(n=12)$ of $8.7 \mathrm{wt} \% \mathrm{Fe}$ and $1081 \mu \mathrm{g} / \mathrm{g} \mathrm{Ge}$.

Gold-bearing arsenopyrite originates from the Ashanti mine in Ghana (AS3999, GH 124) and was previously studied in detail by Oberthür et al. (1994, 1997). Gold mineralisation is related to steep, NNE-SSW to NE-SW trending shear zones predominantly transecting metasediments of the Paleoproterozoic (2.2-2.1 Ga) Birimian Supergroup (Oberthür et al., 1994, 1997). Gold is bimodally distributed either as refractory $\mathrm{Au}$ in sulphide ores with auriferous arsenopyrite as the main ore mineral or as free-milling gold in quartz veins (Oberthür et al., 1994, 1997). Auriferous arsenopyrite is the dominant ore mineral in the Ashanti mine and is accompanied by pyrite, pyrrhotite, and marcasite (Oberthür et al., 1997). EPMA data for arsenopyrite showed that As contents range from 39.4 to $45.9 \mathrm{wt} \%$ with up to $2.02 \mathrm{wt} \% \mathrm{Ni}, 1.17 \mathrm{wt} \% \mathrm{Co}$ and $\mathrm{Sb}$ contents generally below $0.2 \mathrm{wt} \%$ (Oberthür et al., 1994). The As/S ratios are highly variable with lower As/S ratios (27.2-29.4 at\% As) in the core and higher As/S ratios (32.3-33.5 at\% As) in the outer zones (Oberthür et al., 1994). Oberthür et al. (1994, 1997) also studied the micro-distribution of $\mathrm{Au}$ in 

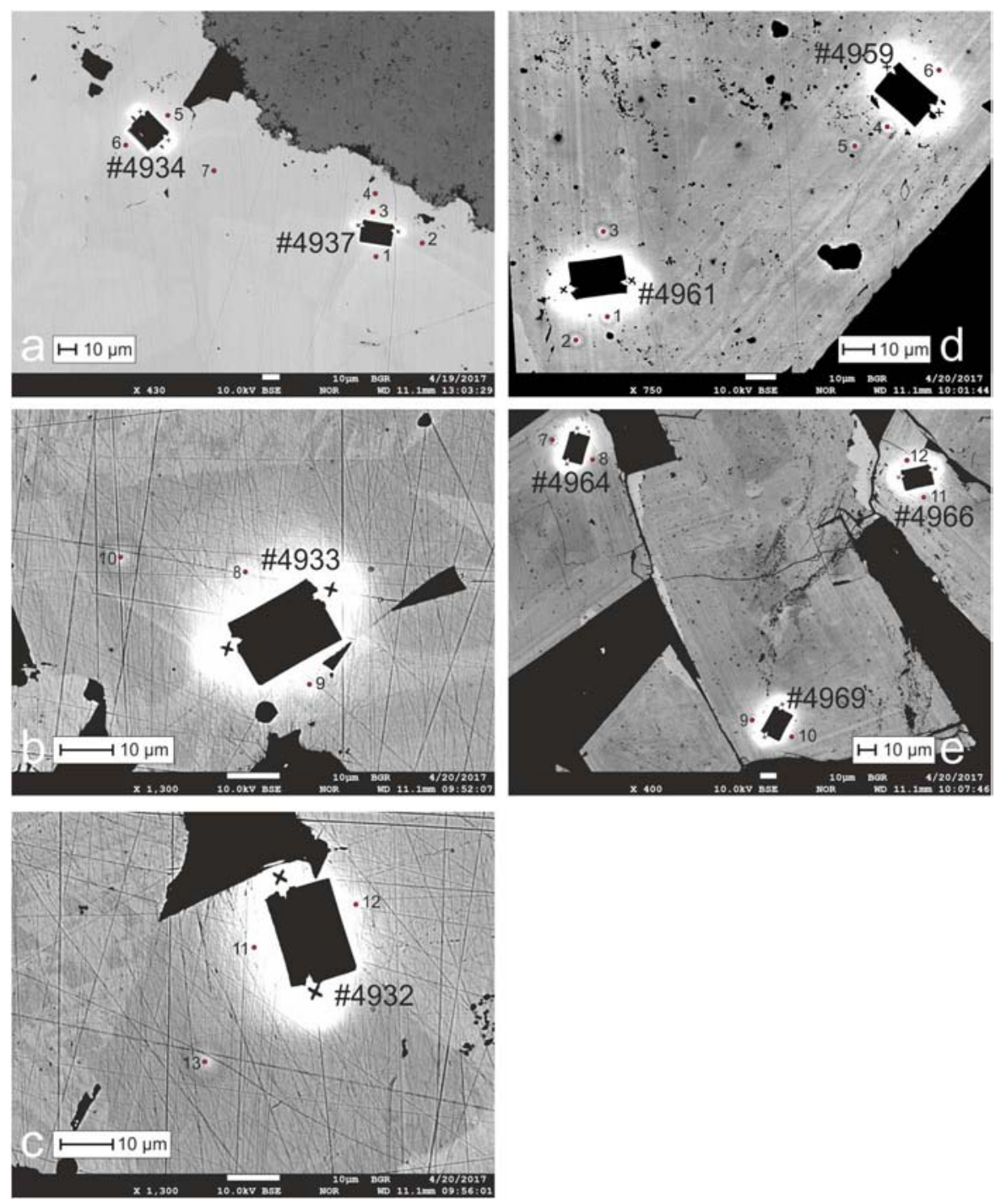

Fig. 1. Backscattered electron images of sphalerite $(a, b, c)$ and arsenopyrite $(d, e)$ showing the locations where electron transparent foils were cut by FIB. The spots of EPMA are also indicated and correspond to the numbers in Tables 3 and 4, respectively.

arsenopyrite by SIMS with Au contents ranging from 1 to $2500 \mu \mathrm{g} / \mathrm{g}$ (mean $190 \mu \mathrm{g} / \mathrm{g}, n=125$ ). There is a general distribution of $\mathrm{Au}$ in arsenopyrite with Au-poor cores and elevated $\mathrm{Au}$ contents along distinct crystal growth zones towards the rim, whereas the outermost layer is usually Au-poor (Oberthür et al., 1994, 1997).

The composition of sphalerite and arsenopyrite was analysed with a JEOL JXA-8530F electron microprobe by wavelength-dispersive spectrometry at the Federal Institute for Geosciences and Natural Resources (BGR) in Hannover using the following analytical conditions: $25 \mathrm{kV}$ acceleration voltage, $100 \mathrm{nA}$ beam current, and measuring time of up to $240 \mathrm{~s}$ on peak. Analytical setup for sphalerite and arsenopyrite including the respective X-ray line, reference material, spectrometer crystal, and measuring time for each element are listed in Tables 1 and 2, respectively. Element distribution maps of arsenopyrite were generated using combined wavelength-dispersive and energy-dispersive X-ray spectrometry.
The combination of FIB with TEM allows a direct link between the crystal and its chemical composition on the $\mathrm{nm}$ scale. The preparation of electron-transparent foils for the TEM investigation was carried out using the site-specific FIB technique at GFZ in Potsdam. For this study, foils with a size of about $15 \times 10 \times 0.15 \mu \mathrm{m}$ from chosen locations within sphalerite and arsenopyrite were sputtered with $\mathrm{Ga}$ ions accelerated to $30 \mathrm{keV}$. For the TEM study, a FEI F20 X-Twin transmission electron microscope with a Schottky field emitter as electron source was used at GFZ. The TEM is equipped with a Gatan Tridiem Imaging Filter, a Fishione High-Angle Annular Dark Field (HAADF) detector allowing for Z-contrast sensitive imaging, and an EDAX energy-dispersive X-ray spectrometer (Wirth et al., 2013). Crystallographic information of nm-sized crystals and host minerals were obtained from fast Fourier transforms (FFT) which have been calculated from high-resolution images (HRTEM). For that purpose, measured $d$-spacings from single-crystal diffraction patterns were compared with 
Table 1. Analytical setup for EPMA by wavelength-dispersive X-ray spectrometry of sphalerite including the X-ray line, reference material, spectrometer crystal, and measuring time for each element.

\begin{tabular}{lcccc}
\hline Element & X-ray line & Standard & Crystal & Time (s) \\
\hline $\mathrm{S}$ & $K \alpha$ & $\mathrm{ZnS}$ & PET & 10 \\
$\mathrm{Fe}$ & $K \alpha$ & $\mathrm{FeS}$ & $\mathrm{LIF}$ & 10 \\
$\mathrm{Cu}$ & $K \alpha$ & $\mathrm{CuFeS}_{2}$ & $\mathrm{LIF}$ & 120 \\
$\mathrm{Zn}$ & $K \alpha$ & $\mathrm{ZnS}$ & $\mathrm{LIF}$ & 10 \\
$\mathrm{Ge}$ & $K \alpha$ & metal & LIF & 120 \\
$\mathrm{As}$ & $L \alpha$ & $\mathrm{GaAs}$ & $\mathrm{TAP}$ & 120 \\
$\mathrm{Se}$ & $L \alpha$ & $\mathrm{InSe}$ & $\mathrm{TAP}$ & 120 \\
$\mathrm{Cd}$ & $L \beta$ & $\mathrm{CdS}$ & PET & 100 \\
$\mathrm{In}$ & $L \alpha$ & $\mathrm{InSe}$ & PET & 120 \\
\hline
\end{tabular}

Table 2. Analytical setup for EPMA wavelength-dispersive X-ray spectrometry of arsenopyrite including the X-ray line, reference material, spectrometer crystal, and measuring time for each element.

\begin{tabular}{lcccc}
\hline Element & X-ray line & Standard & Crystal & Time (s) \\
\hline $\mathrm{S}$ & $K \alpha$ & $\mathrm{FeAsS}$ & PET & 10 \\
$\mathrm{Fe}$ & $K \alpha$ & $\mathrm{FeAsS}$ & $\mathrm{LIF}$ & 10 \\
$\mathrm{Co}$ & $K \alpha$ & $(\mathrm{Co}, \mathrm{Ni}, \mathrm{Fe}) \mathrm{AsS}$ & $\mathrm{LIF}$ & 100 \\
$\mathrm{Ni}$ & $K \alpha$ & $(\mathrm{Co}, \mathrm{Ni}, \mathrm{Fe}) \mathrm{AsS}$ & $\mathrm{LIF}$ & 100 \\
$\mathrm{As}$ & $L \alpha$ & $\mathrm{FeAsS}$ & $\mathrm{TAP}$ & 10 \\
$\mathrm{Sb}$ & $L \alpha$ & $\mathrm{Sb}_{2} \mathrm{Sb}_{3}$ & PET & 120 \\
$\mathrm{Au}$ & $M \alpha$ & metal & PET & 240 \\
\hline
\end{tabular}

calculated $d$-spacings from the literature (American Mineralogist Crystal Structure Database) by measuring the distance between Bragg reflections and the angles between the individual reflections. Chemical compositions of phases were measured with an EDAX energy-dispersive X-ray spectrometer in the Scanning Transmission Electron Microscopy (STEM) mode. For detailed descriptions of the FIB sample preparation technique please refer to Wirth (2004, 2009) and Wirth et al. (2013).

\section{Results}

\subsection{Distribution of $\mathrm{Ge}$ in sphalerite from Tres Marias, Mexico}

The Ge contents in sphalerite from Tres Marias are confirmed by EPMA measurements close to the position of the FIB cuts (Figs. 1a-1c). Germanium-bearing sphalerite (number of spot analyses $n=8$, Table 3 ) has $\mathrm{S}$ contents between 31.65 and $32.34 \mathrm{wt} \%$ (median $=32.03 \mathrm{wt} \%$ ), $\mathrm{Zn}$ concentrations ranging from 58.48 to $61.27 \mathrm{wt} \%$ (median $=59.24 \mathrm{wt} \%$ ), and $\mathrm{Fe}$ contents varying from 3.97 to $6.63 \mathrm{wt} \%$ (median $=6.20 \mathrm{wt} \%)$, respectively. Cadmium (from $c a .2200$ up to $3600 \mu \mathrm{g} / \mathrm{g}$, median $\approx 2800 \mu \mathrm{g} / \mathrm{g}$ ) occurs as minor element in Ge-rich sphalerite. Germanium concentrations range from 150 to $1430 \mu \mathrm{g} / \mathrm{g}$ (median $\approx 940 \mu \mathrm{g} / \mathrm{g}$ ). In contrast, Ge-free (Ge below EPMA detection limit) sphalerite (number of spot analyses $n=5$, Table 3) is characterised by higher $\mathrm{Cd}$ (ca. 3100 to $9650 \mu \mathrm{g} / \mathrm{g}$, median $=3300 \mu \mathrm{g} / \mathrm{g}$ ), but slightly lower Fe contents between 3.69 and $5.60 \mathrm{wt} \%$ (median $=5.42 \mathrm{wt} \%$ ). The major elements in Ge-free sphalerite range from 31.76 to $32.57 \mathrm{wt} \% \mathrm{~S}$ (median $=31.85 \mathrm{wt} \%$ ) and from 58.56 to $61.87 \mathrm{wt} \% \mathrm{Zn}($ median $=60.29 \mathrm{wt} \%)$. Other trace elements like $\mathrm{Cu}$, As, Se and In are below or close to the detection limit of EPMA in Ge-rich as well as in Ge-free sphalerite.

No discrete Ge-phases were detected by TEM in all analysed FIB foils from sphalerite arguing for a homogenous incorporation of Ge into the sphalerite lattice. As peculiarity,

Table 3. Results of EPMA of Ge-bearing and Ge-free sphalerite. Data are given as weight percent for each element (upper part) and as atoms per formula unit normalised to 2 (lower part). The spot for each analysis is indicated on Figs. 1a-1c. b.d.l. = below detection limit.

\begin{tabular}{|c|c|c|c|c|c|c|c|c|c|c|c|c|c|}
\hline \multirow[b]{2}{*}{ Analysis } & \multicolumn{8}{|c|}{ Ge-bearing sphalerite } & \multicolumn{5}{|c|}{ Ge-free sphalerite } \\
\hline & 2 & 4 & 5 & 8 & 9 & 10 & 11 & 13 & 1 & 3 & 6 & 7 & 12 \\
\hline $\bar{S}$ & 32.10 & 32.34 & 31.95 & 31.89 & 31.81 & 32.33 & 31.65 & 32.19 & 31.76 & 31.85 & 31.86 & 32.57 & 31.85 \\
\hline $\mathrm{Fe}$ & 5.72 & 6.27 & 6.13 & 6.43 & 3.97 & 6.63 & 5.52 & 6.27 & 5.60 & 4.30 & 5.43 & 5.42 & 3.69 \\
\hline $\mathrm{Cu}$ & b.d.l. & b.d.l. & 0.010 & b.d.l. & 0.004 & 0.002 & b.d.l. & 0.002 & b.d.l. & 0.004 & b.d.l. & b.d.l. & b.d.l. \\
\hline $\mathrm{Zn}$ & 59.52 & 59.09 & 58.48 & 58.79 & 61.27 & 58.80 & 59.50 & 59.40 & 58.56 & 60.33 & 59.83 & 60.29 & 61.87 \\
\hline $\mathrm{Ge}$ & 0.015 & 0.027 & 0.115 & 0.103 & 0.030 & 0.085 & 0.143 & 0.117 & b.d.1. & b.d.1. & b.d.l. & b.d.l. & b.d.l. \\
\hline As & 0.017 & b.d.1. & b.d.1. & b.d.1. & 0.006 & 0.023 & b.d.1. & 0.007 & b.d.1. & 0.007 & b.d.1. & b.d.1. & b.d.l. \\
\hline $\mathrm{Se}$ & b.d.l. & 0.004 & b.d.l. & b.d.l. & b.d.1. & b.d.l. & b.d.1. & b.d.1. & b.d.1. & 0.007 & 0.007 & 0.009 & b.d.l. \\
\hline $\mathrm{Cd}$ & 0.362 & 0.275 & 0.220 & 0.276 & 0.335 & 0.336 & 0.238 & 0.282 & 0.966 & 0.571 & 0.330 & 0.310 & 0.330 \\
\hline In & b.d.l. & b.d.1. & b.d.1. & b.d.1. & b.d.1. & b.d.1. & b.d.1. & b.d.1. & b.d.1. & b.d.l. & b.d.1. & b.d.1. & b.d.1. \\
\hline Total & 97.73 & 98.00 & 96.91 & 97.49 & 97.43 & 98.21 & 97.05 & 98.26 & 96.89 & 97.07 & 97.46 & 98.60 & 97.74 \\
\hline Z & 2 & 2 & 2 & 2 & 2 & 2 & 2 & 2 & 2 & 2 & 2 & 2 & 2 \\
\hline$S$ & 0.992 & 0.995 & 0.994 & 0.988 & 0.990 & 0.993 & 0.987 & 0.990 & 0.993 & 0.994 & 0.989 & 0.997 & 0.989 \\
\hline $\mathrm{Fe}$ & 0.102 & 0.111 & 0.110 & 0.114 & 0.071 & 0.117 & 0.099 & 0.111 & 0.101 & 0.077 & 0.097 & 0.095 & 0.066 \\
\hline $\mathrm{Cu}$ & & & 0.000 & & 0.000 & 0.000 & & 0.000 & & 0.000 & & & \\
\hline $\mathrm{Zn}$ & 0.903 & 0.892 & 0.893 & 0.894 & 0.935 & 0.886 & 0.910 & 0.896 & 0.898 & 0.924 & 0.911 & 0.905 & 0.942 \\
\hline $\mathrm{Ge}$ & 0.000 & 0.000 & 0.002 & 0.001 & 0.000 & 0.001 & 0.002 & 0.002 & & & & & \\
\hline As & 0.000 & & & & 0.000 & 0.000 & & 0.000 & & 0.000 & & & \\
\hline $\mathrm{Se}$ & & 0.000 & & & & & & & & 0.000 & 0.000 & 0.000 & \\
\hline $\mathrm{Cd}$ & 0.003 & 0.002 & 0.002 & 0.002 & 0.003 & 0.003 & 0.002 & 0.002 & 0.009 & 0.005 & 0.003 & 0.003 & 0.003 \\
\hline
\end{tabular}




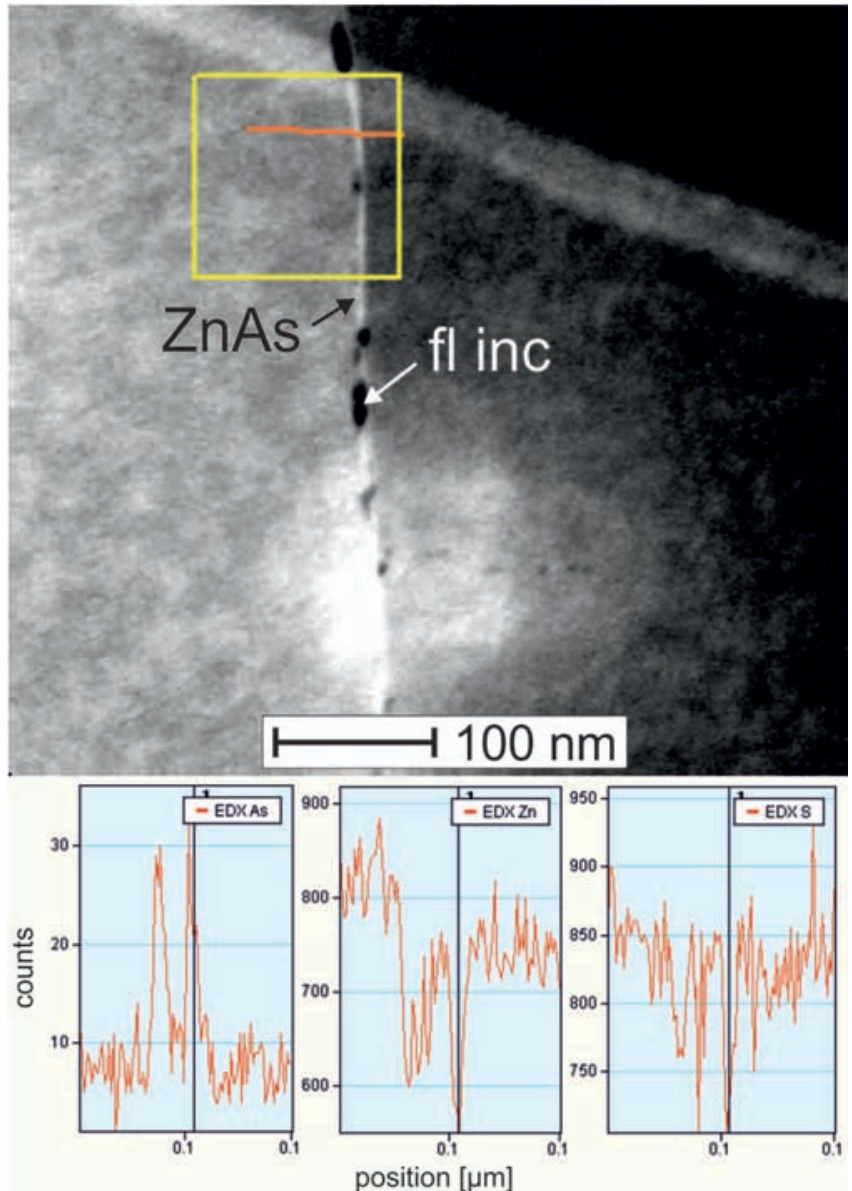

Fig. 2. Upper row: TEM image of grain boundary in sphalerite (foil \#4932). High-Angle Annular Dark Field (HAADF) image showing fluid inclusions (fl inc, dark spots along grain boundary) and As-rich zone (ZnAs, bright zone along grain boundary). The orange line indicates the position of the EDX line scan across the As-rich zone. Lower row: Element concentration distribution along the EDX line scan for As, Zn and S.

a 10-15 nm thick grain boundary in sphalerite (\#4932) was observed by TEM where fluid inclusions are aligned like pearls on a string (Fig. 2). Next to the fluid inclusions, a brighter As-rich area was detected along the grain boundary. Line scans with EDX analysis indicate an area of about $5 \mathrm{~nm}$ in width with increasing As values and simultaneously decreasing $\mathrm{Zn}$ and $\mathrm{S}$ concentrations. Electron diffraction patterns show that the As-rich phase represents the orthorhombic ZnAs (Fischer et al., 2014).

\subsection{Distribution of Au in arsenopyrite from Ashanti, Ghana}

Arsenopyrite generally occurs as idiomorphic rhomb-shaped crystals ranging in size between 50 and $200 \mu \mathrm{m}$, but may locally reach up to several millimetres (Oberthür et al., 1997). Element distribution maps obtained by EPMA were used to identify Au-enriched zones in the arsenopyrite for the preparation of the FIB foils (Figs. 3a and 3d). The arsenopyrite grains are chemically heterogeneous and show concentric growth zoning. The cores of the arsenopyrite crystals are Au-poor, whereas elevated $\mathrm{Au}$ concentrations are observed in zones towards the rim followed by Au-poor outer rims. This confirms the observations of Oberthür et al. (1994, 1997). The element distribution maps also show variable As/S ratios within the arsenopyrite crystals, which typically increase stepped from core to rim of each grain (Figs. 3b, 3c, 3e, 3f).

The Au-rich zones in arsenopyrite were measured by EPMA and the analytical spots were positioned close to the FIB cuts (Figs. 1d and 1e). The spot analyses (number of measurements $n=12$, Table 4 ) show that the composition for the major elements ranges from 34.58 to $35.18 \mathrm{wt} \%$ Fe (median $=34.95 \mathrm{wt} \%$ ), from 40.07 to $42.04 \mathrm{wt} \%$ As $($ median $=41.04 \mathrm{wt} \%)$, and from 21.34 to $22.55 \mathrm{wt} \%$ $\mathrm{S}$ (median $=21.85 \mathrm{wt} \%)$. The As/S ratios are rather low (with 28.12-29.75 at\% As) in the Au-bearing zones. Nickel contents vary between $c a .170$ and $1060 \mu \mathrm{g} / \mathrm{g} \mathrm{Ni}$ (median $\approx$ $300 \mu \mathrm{g} / \mathrm{g}$ ), whereas $\mathrm{Co}$ and $\mathrm{Sb}$ are generally below the detection limit of EPMA. Gold concentrations are high ranging between $c a$. 400 and $3070 \mu \mathrm{g} / \mathrm{g} \mathrm{Au}$ (median $\approx 1900 \mu \mathrm{g} / \mathrm{g}$ ).

Two types of nm-sized gold particles were identified by TEM in FIB foils (\#4959, \#4964, \#4966) from auriferous arsenopyrite: elongated, rod-like Au grains about $40 \mathrm{~nm}$ in length and $5 \mathrm{~nm}$ in thickness (Fig. 4a) as well as roundish gold grains about $8 \mathrm{~nm}$ in diameter. At least the elongated gold grains are oriented parallel to each other within arsenopyrite. Additionally, fluid inclusions are observed in arsenopyrite containing discrete nm-sized gold grains of up to $50 \mathrm{~nm}$ in diameter (Fig. 4b).

\section{Discussion}

\subsection{Sphalerite - solid-solution of Ge}

In general, the substitution of trace elements into a solid phase is controlled by the nature of the bonding, the size of the lattice site, and the charge balance (e.g., Johan, 1988; Belissont et al., 2014). Sphalerite has a cubic crystal structure with tetrahedral coordination of $\mathrm{Zn}$ and $\mathrm{S}$ (Vaughan \& Craig, 1978). Germanium-bearing sphalerite from Tres Marias shows a positive correlation of Ge enrichment with Fe (Cook et al., 2009; Saini-Eidukat et al., 2009), which suggests coupled substitution of $\mathrm{Ge}$ and $\mathrm{Fe}$ for $\mathrm{Zn}$ (Cook et al., 2009). However, Cook et al. (2015) state that there is no correlation and no evidence for coupled substitution. Additionally, Cook et al. (2015) confirmed by XANES that $\mathrm{Ge}$ is present as $\mathrm{Ge}^{4+}$ within Fe-rich sphalerite, which implies substitution of $\mathrm{Zn}^{2+}$ in Fe-rich zones by $\mathrm{Ge}^{4+}$, with coupled generation of vacancies. The ionic radii of $\mathrm{Zn}, \mathrm{Fe}$ and $\mathrm{Ge}$ in tetrahedral coordination are ${ }^{\mathrm{IV}} \mathrm{Zn}^{2+}=0.6 \AA$, ${ }^{\mathrm{IV}} \mathrm{Fe}^{2+}=0.63 \AA$ and ${ }^{\mathrm{IV}} \mathrm{Ge}^{4+}=0.39 \AA$ (Shannon, 1976). This indicates that direct substitution of $\mathrm{Zn}$ by Fe is possible, but this also implies that the substitution of $\mathrm{Ge}$ for $\mathrm{Zn}$ is unlikely when applying the rules of Goldschmidt (1926) that the ionic radii should not differ by less than $15 \%$. However, the generation of vacancies for charge balance probably 

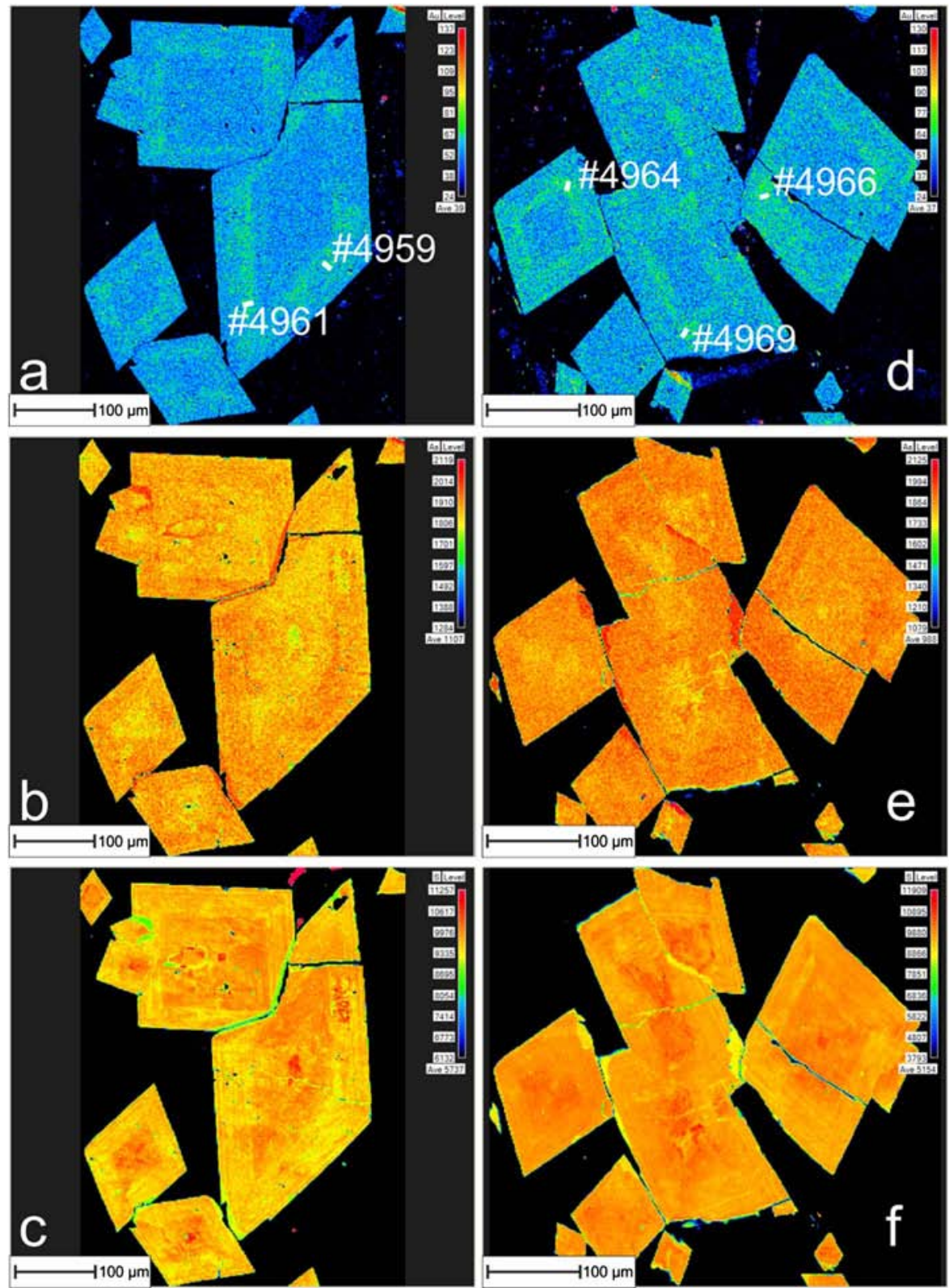

Fig. 3. EPMA false colour element maps of Au (a, d), As (b, e) and S (c, f) on idiomorphic arsenopyrite crystals. White bars indicate the location where electron transparent foils were cut.

enables the incorporation of Ge into the sphalerite structure, and this effect is possibly facilitated by elevated $\mathrm{Fe}$ contents in sphalerite.

\subsection{Arsenopyrite - nanometre-sized inclusions}

Element distribution maps of arsenopyrite crystals obtained by EPMA showed: (1) concentric growth zoning with Au-poor cores followed by Au-enriched zones and finally Au-poor rims, and (2) chemical heterogeneity with increasing $\mathrm{As} / \mathrm{S}$ ratios from centre to the rim (Fig. 3). Natural arsenopyrite is commonly zoned with a S-rich centre and an As-rich rim (Kretschmar \& Scott, 1976). EPMA data for the Au-rich zones show that arsenopyrite is deficient in As compared to its stoichiometric composition resulting in a low As/S ratio which was reported from auriferous arsenopyrite elsewhere (Genkin et al., 1998; Vaughan \& Kyin, 2004; Sung et al., 2009). Compositional zoning and As deficiency reflect local disequilibrium during growth and local fluctuations in the activity of $\mathrm{S}$ and As (Kretschmar \& Scott, 1976; Vaughan \& Kyin, 2004). Arsenopyrite is the most refractory of the common sulphides, which means that the crystals do not readily reequilibrate and the composition, therefore, reflects the conditions present during growth (Kretschmar \& Scott, 1976). These observations reflect a multistage evolution and the 
Table 4. Results of EPMA of Au-bearing arsenopyrite. Data are given as weight percent for each element (upper part) and as atoms per formula unit normalised to 3 (lower part). The spot for each analysis is indicated on Figs. 1d and 1e. b.d.1. = below detection limit.

\begin{tabular}{lccccccccccccc}
\hline Point & 1 & 2 & 3 & 4 & 5 & 6 & 7 & 8 & 9 & 10 & 11 \\
\hline $\mathrm{S}$ & 21.75 & 21.77 & 21.77 & 21.34 & 21.77 & 22.03 & 22.08 & 22.55 & 21.93 & 22.11 & 22.20 & 21.57 \\
$\mathrm{Fe}$ & 34.65 & 34.94 & 34.82 & 34.74 & 35.04 & 34.95 & 35.07 & 35.18 & 35.01 & 34.92 & 35.10 & 34.58 \\
$\mathrm{Co}$ & b.d.1. & b.d.1. & b.d.1. & b.d.1. & b.d.1. & b.d.1. & 0.002 & b.d.1. & 0.001 & b.d.1. & 0.005 & 0.008 \\
$\mathrm{Ni}$ & 0.030 & 0.029 & 0.019 & 0.021 & 0.036 & 0.021 & 0.053 & 0.017 & 0.038 & 0.022 & 0.048 & 0.106 \\
$\mathrm{As}$ & 40.90 & 41.94 & 41.56 & 41.32 & 42.04 & 41.04 & 40.07 & 40.76 & 40.58 & 41.04 & 40.98 & 41.23 \\
$\mathrm{Sb}$ & b.d.1. & b.d.1. & b.d.1. & b.d.1. & b.d.1. & b.d.1. & b.d.1. & b.d.1. & b.d.1. & b.d.1. & b.d.1. & b.d.1. \\
$\mathrm{Au}$ & 0.254 & 0.040 & 0.196 & 0.205 & 0.218 & 0.153 & 0.199 & 0.171 & 0.072 & 0.165 & 0.185 & 0.307 \\
Total & 97.58 & 98.72 & 98.37 & 97.63 & 99.10 & 98.19 & 97.47 & 98.68 & 97.63 & 98.26 & 98.52 & 97.80 \\
$\mathrm{Z}$ & 3 & 3 & 3 & 3 & 3 & 3 & 3 & 3 & 3 & 3 & 3 & 3 \\
$\mathrm{~S}$ & 1.102 & 1.092 & 1.096 & 1.085 & 1.090 & 1.107 & 1.115 & 1.123 & 1.107 & 1.110 & 1.111 & 1.093 \\
$\mathrm{Fe}$ & 1.008 & 1.006 & 1.006 & 1.014 & 1.007 & 1.008 & 1.017 & 1.006 & 1.015 & 1.006 & 1.009 & 1.006 \\
$\mathrm{Co}$ & & & & & & & 0.000 & & 0.000 & 0.000 & \\
$\mathrm{Ni}$ & 0.001 & 0.001 & 0.001 & 0.001 & 0.001 & 0.001 & 0.001 & 0.000 & 0.001 & 0.001 & 0.001 & 0.003 \\
$\mathrm{As}$ & 0.887 & 0.900 & 0.895 & 0.899 & 0.901 & 0.883 & 0.866 & 0.869 & 0.877 & 0.882 & 0.878 & 0.894 \\
$\mathrm{Sb}$ & & & & & & & & & & \\
$\mathrm{Au}$ & 0.002 & 0.000 & 0.002 & 0.002 & 0.002 & 0.001 & 0.002 & 0.001 & 0.001 & 0.001 & 0.002 & 0.003 \\
\hline
\end{tabular}
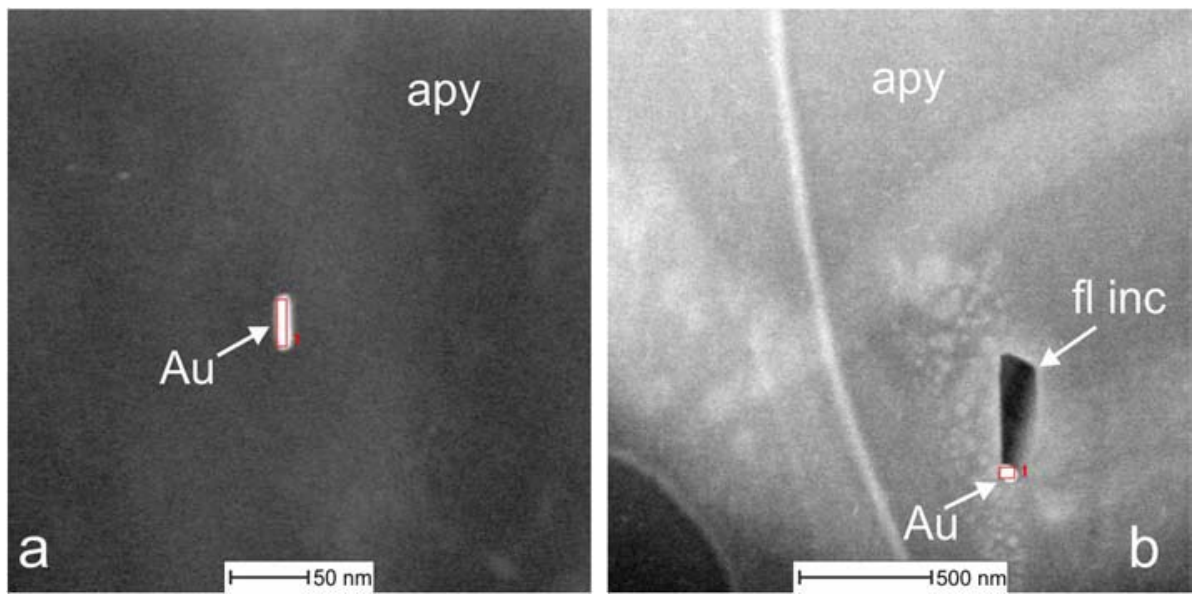

Fig. 4. TEM images of nanometre-sized gold grains $(\mathrm{Au})$ in arsenopyrite (apy). (a) HAADF image of rod-like gold grain in arsenopyrite (foil \#4966). (b) HAADF image gold grain in fluid inclusion (fl inc) in arsenopyrite (foil \#4964).

chemical change of the mineralising system during formation of arsenopyrite, which probably triggered precipitation of $\mathrm{Au}$ cogenetically with arsenopyrite along growth zones.

Transmission electron microscopy of FIB foils from the Au-enriched zones identified that Au occurs as nm-sized native $\mathrm{Au}$ particles in two different habit types, namely rod-like and roundish grains. It is reasonable that the roundish gold grains represent rod-like gold grains of differing orientation, which are cut more or less perpendicular to their longitudinal axis. This indicates that the nm-sized gold particles are present in at least two distinct orientations within arsenopyrite. The additional occurrence of native Au grains in fluid inclusions (Fig. 4b) is evidence for a hydrothermal transport of $\mathrm{Au}$, most likely as bisulfide complexes (Wood \& Samson, 1998). The nm-sized Au grains were perhaps formed by exsolution, but exsolution of gold is unlikely as the concentration of maximum $3070 \mu \mathrm{g} / \mathrm{g} \mathrm{Au}$ is, according to Reich et al. (2005), significantly below the solubility limit of $2 \mathrm{wt} \% \mathrm{Au}$ in arsenopyrite. All observations combined argue for an enrichment of $\mathrm{Au}$ at the interface (crystallisation front) of crystallising arsenopyrite with the hydrothermal fluid and subsequent nucleation of $\mathrm{Au}$ at the surface of arsenopyrite after the critical concentration for nucleation was overstepped. The arsenopyrite lattice facilitated nucleation and oriented growth of $\mathrm{Au}$ simultaneously with arsenopyrite. The concentric zone of $\mathrm{Au}$ enrichment is parallel to the euhedral crystal boundaries, which indicates that precipitation of $\mathrm{Au}$ was cogenetic with growth of arsenopyrite. This mechanism is common in nature; for example, oriented sub-microscopic pyrrhotite inclusions are observed in apatite (Gottesmann \& Wirth, 1997).

\section{Conclusions}

The combination of FIB and TEM with EPMA is a useful tool in characterising the siting of trace elements in situ in 
their host minerals and can therefore be used for genetic implications of ore-forming processes. The example of $\mathrm{Au}$ in arsenopyrite of the present study demonstrates that submicroscopic discrete phases may cause the observed trace element concentrations visible at larger scale. On the contrary, Ge-rich sphalerite from Tres Marias is an example for homogeneous trace-element distribution in the crystal structure. The main results are:

1. Sphalerite from Tres Marias contains Ge concentrations of up to $c a .1430 \mu \mathrm{g} / \mathrm{g}$ and is characterised by elevated Fe contents. Germanium is homogeneously distributed in the sphalerite structure without the presence of distinct Ge-bearing phases in the form of inclusions or exsolutions.

2. Gold is present in distinct growth zones in arsenopyrite from the Ashanti deposit at concentration levels of up to $3000 \mu \mathrm{g} / \mathrm{g}$ Au. Orientated native $\mathrm{Au}$ crystals occur in the Au-enriched zones in arsenopyrite showing at least two distinct orientations. This argues for nucleation and oriented growth of native Au particles at the interface of crystallising arsenopyrite with hydrothermal fluid after a critical Au concentration is exceeded.

Acknowledgements: Frank Melcher and Thomas Oberthür collected the samples during former projects. We gratefully acknowledge the preparation of excellent polished sections by Peter Rendschmidt and Don Henry. We also want to thank Reto Gieré for editorial handling and two anonymous reviewers for helpful comments, which considerably improved the manuscript.

\section{References}

Belissont, R., Boiron, M.-C., Luais, B., Cathelineau, M. (2014): LAICP-MS analyses of minor and trace elements and bulk Ge isotopes in zoned Ge-rich sphalerites from the Noailhac-SaintSalvy deposit (France): Insights into incorporation mechanisms and ore deposition processes. Geochim. Cosmochim. Acta, 126, 518-540.

Bernstein, L.R. (1985): Germanium geochemistry and mineralogy. Geochim. Cosmochim. Acta, 49, 2409-2422.

Cabri, L.J., Blank, H., El Goresy, A., Laflamme, J.H.G., Nobling, R., Sizgoric, M., Traxel, K. (1984): Quantitative trace-element analyses of sulfides from Sudbury and Stillwater by proton microprobe. Can. Mineral., 22, 521-542.

Cabri, L.J., Chryssoulis, S.L., De Villiers, J.P.R., Laflamme, J.H.G., Buseck, P.R. (1989): The nature of "invisible" gold in arsenopyrite. Can. Mineral., 27, 353-362.

Cabri, L.J., Newville, M., Gordon, R.A., Crozier, E.D., Sutton, S.R., McMahon, G., Jiang, D.-T. (2000): Chemical speciation of gold in arsenopyrite. Can. Mineral., 38, 1265-1281.

Cathelineau, M., Boiron, M.-C., Holliger, P., Marion, P., Denis, M. (1989): Gold in arsenopyrites: crystal chemistry, location and state, physical and chemical conditions of deposition. Econ. Geol. Monograph, 6, 328-341.

Cepedal, A., Fuertes-Fuente, M., Martin-Izard, A., González-Nistral, S., Barrero, M. (2008): Gold-bearing As-rich pyrite and arsenopyrite from the El Valle gold deposit, Asturias, Northwestern Spain. Can. Mineral., 46, 233-247.

Ciobanu, C.L., Cook, N.J., Utsunomiya, S., Pring, A., Green, L. (2011): Focussed ion beam-transmission electron microscopy applications in ore mineralogy: Bridging micro- and nanoscale observations. Ore Geol. Rev., 42, 6-31.

Ciobanu, C.L., Cook, N.J., Ehrig, K. (2017): Ore minerals down to the nanoscale: $\mathrm{Cu}-(\mathrm{Fe})$-sulphides from the iron oxide copper gold deposit at Olympic Dam, South Australia. Ore Geol. Rev., 81, 1218-1235.

Cook, N.J. \& Chryssoulis, S.L. (1990): Concentrations of “invisible gold" in common sulfides. Can. Mineral., 28, 1-16.

Cook, N.J., Ciobanu, C.L., Pring, A., Skinner, W., Shimizu, M., Danyushevsky, L., Saini-Eidukat, B., Melcher, F. (2009): Trace and minor elements in sphalerite: A LA-ICPMS study. Geochim. Cosmochim. Acta, 73, 4761-4791.

Cook, N.J., Ciobanu, C.L., Meria, D., Silcock, D., Wade, B. (2013): Arsenopyrite-pyrite association in an orogenic gold ore: tracing mineralization history from textures and trace elements. Econ. Geol., 108, 1273-1283.

Cook, N.J., Etschmann, B., Ciobanu, C.L., Geraki, K., Howard, D.L., Williams, T., Rae, N., Pring, A., Chen, G., Johannessen, B., Brugger, J. (2015): Distribution and Substitution Mechanism of $\mathrm{Ge}$ in a $\mathrm{Ge}-(\mathrm{Fe})-\mathrm{Bearing}$ Sphalerite. Minerals, 5, 117-132.

Cook, N.J., Ciobanu, C.L., George, L., Zhu, Z.-Y., Wade, B., Ehrig, K. (2016): Trace Element Analysis of Minerals in Magmatic-Hydrothermal Ores by Laser Ablation InductivelyCoupled Plasma Mass Spectrometry: Approaches and Opportunities. Minerals, 6, 111.

Fischer, A., Eklöf, D., Benson, D.E., Wu, Y., Scheidt, E.-W., Scherer, W., Häussermann, U. (2014): Synthesis, structure, and properties of the electron-poor II-V semiconductor ZnAs. Inorg. Chem., 53, 8691-8699.

Fleet, M.E. \& Mumin, A.H. (1997): Gold-bearing arsenian pyrite and marcasite and arsenopyrite from Carlin Trend gold deposits and laboratory synthesis. Am. Mineral., 82, 182-193.

Fleischer, M. (1955): Minor elements in some sulfide minerals. in "Economic Geology 50th Anniversary Volume", Bateman, A.M. \& Bateman, A.M., eds. Economic Geology Publishing Co, El Paso, 970-1024.

Genkin, A.D., Bortnikov, N.S., Cabri, L.J., Wagner, F.E., Stanley, C.J., Safonov, Y.G., McMahon, G., Friedl, J., Kerzin, A.L., Gamyanin, G.N. (1998): A multidisciplinary study of invisible gold in arsenopyrite from four mesothermal gold deposits in Siberia, Russian Federation. Econ. Geol., 93, 463-487.

Goldschmidt, V.M. (1926): Geochemische Verteilungsgesetze der Elemente Vol. VII: Gesetze der Krystallochemie. Skrifter utgitt av det Norske Videnskaps Akademi i Oslo, 1. Matematisknaturvidenskapelig klasse, Oslo, $117 \mathrm{p}$.

Gottesmann, B. \& Wirth, R. (1997): Pyrrhotite inclusions in dark pigmented apatite from granitic rocks. Eur. J. Mineral., 9, 491-500.

Höll, R., Kling, M., Schroll, E. (2007): Metallogenesis of germanium - A review. Ore Geol. Rev., 30, 145-180.

Johan, Z. (1988): Indium and germanium in the structure of sphalerite: an example of coupled substitution with copper. Mineral. Petrol., 39, 211-229.

Johan, Z., Marcoux, E., Bonnemaison, M. (1989): Arsenopyrite aurifère: mode de substitution de Au dans la structure de FeAsS. C. R. Acad. Sci. II, 308, 185-191.

Junge, M., Wirth, R., Oberthür, T., Melcher, F., Schreiber, A. (2015): Mineralogical siting of platinum-group elements in pentlandite from the Bushveld Complex, South Africa. Miner. Deposita, 50, 41-54.

Kretschmar, U. \& Scott, S.D. (1976): Phase relations involving arsenopyrite in the system Fe-As-S and their application. Can. Mineral., 14, 364-386.

McClenaghan, S.H., Lentz, D.R., Cabri, L.J. (2004): Abundance and speciation of gold in massive sulfides of the Bathurst Mining Camp, New Brunswick, Canada. Can. Mineral., 42, 851-871. 
Melcher, F., Buchholz, P. (2014): Germanium. in "Critical Metals Handbook', Gunn, G., ed. John Wiley \& Sons, Chichester, 177-203.

Oberthür, T., Vetter, U., Schmidt Mumm, A., Weiser, T., Amanor, J.A., Gyapong, W.A., Kumi, R., Blenkinsop, T.G. (1994): The Ashanti gold mine at Obuasi, Ghana: mineralogical, geochemical, stable isotope and fluid inclusions studies on the metallogenesis of the deposit. Geol. Jahrb., D 100, 31-129.

Oberthür, T., Weiser, T., Amanor, J.A., Chryssoulis, S.L. (1997): Mineralogical siting and distribution of gold in quartz veins and sulfide ores of the Ashanti mine and other deposits in the Ashanti belt of Ghana: genetic implications. Miner. Deposita, 32, 2-15.

Ostendorf, J., Henjes-Kunst, F., Schneider, J., Melcher, F., Gutzmer, J. (2017): Genesis of the carbonate-hosted Tres Marias Zn-Pb(Ge) deposit, Mexico: constraints from $\mathrm{Rb}-\mathrm{Sr}$ sphalerite geochronology and $\mathrm{Pb}$ isotopes. Econ. Geol., 112, 1075-1087.

Reich, M., Kesler, S.E., Utsunomiya, S., Palenik, C.S., Chryssoulis, S.L., Ewing, R.C. (2005): Solubility of gold in arsenian pyrite. Geochim. Cosmochim. Acta, 69, 2781-2796.

Saini-Eidukat, B., Melcher, F., Lodziak, J. (2009): Zinc-germanium ores of the Tres Marias Mine, Chihuahua, Mexico. Miner. Deposita, 44, 363-370.

Saini-Eidukat, B., Melcher, F., Göttlicher, J., Steininger, R. (2016): Chemical environment of unusually $\mathrm{Ge}$ - and $\mathrm{Pb}$-rich willemite, Tres Marias Mine, Mexico. Minerals, 6, 20.

Shannon, R.D. (1976): Revised effective ionic radii and systematic studies of interatomic distances in halides and chalcogenides. Acta Crystallogr. A, 32, 751-767.

Sung, Y.-H., Brugger, J., Ciobanu, C. L., Pring, A., Skinner, W., Nugus, M. (2009): Invisible gold in arsenian pyrite and arsenopyrite from a multistage Archaean gold deposit: Sunrise Dam, Eastern Goldfields Province, Western Australia. Miner. Deposita, 44, 765-791.

Seredin, V.V. (2012): From coal science to metal production and environmental protection: A new story of success. Int. J. Coal Geol., 90, 1-3.
Vaughan, D.J. \& Craig, J.R. (1978): Mineral chemistry of metal sulfides. Cambridge University Press, Cambridge.

Vaughan, J.P. \& Kyin, A. (2004): Refractory gold ores in Archaean greenstones, Western Australia: mineralogy, gold paragenesis, metallurgical characterization and classification. Mineral. Mag., 68, 255-277.

Wirth, R. (2004): Focused Ion Beam (FIB): A novel technology for advanced application of micro- and nanoanalysis in geosciences and applied mineralogy. Eur. J. Mineral., 16, 863-876.

- (2009): Focused Ion Beam (FIB) combined with SEM and TEM: Advanced analytical tools for studies of chemical composition, microstructure and crystal structure in geomaterials on a nanometre scale. Chem. Geol., 261, 217-229.

Wirth, R., Reid, D., Schreiber, A. (2013): Nanometer-sized Platinum-Group Minerals (PGM) in base metal sulfides: new evidence for an orthomagmatic origin of the Merensky Reef PGE ore deposit, Bushveld Complex, South Africa. Can. Mineral., 51, 143-155.

Wood, S.A. \& Samson, I.M. (1998): Solubility of ore minerals and complexation of ore metals in hydrothermal solutions. Rev. Econ Geol., 10, 33-80.

Yang, S., Blum, N., Rhaders, E., Zhang, Z. (1998): The nature of invisible gold in sulfides from the Xiangxi Au-Sb-W ore deposit in Northwestern Hunan, People's Republic of China. Can. Mineral., 36, 1361-1372.

Ye, L., Cook, N.J., Ciobanu, C.L., Yuping, L, Qian, Z., Tiegeng, K., Wei, G., Yulong, Y, Danyushevskiy, L. (2011): Trace and minor elements in sphalerite from base metal deposits in South China: A LA-ICPMS study. Ore Geol. Rev., 39, 188-217.

Received 26 January 2018

Modified version received 29 June 2018

Accepted 26 August 2018 